Summer 6-1-2006

\title{
Performing Remediation: The Minstrel, The Camera, and The Octoroon
}

Adam Sonstegard

Cleveland State University, a.sonstegard@csuohio.edu

Follow this and additional works at: https://engagedscholarship.csuohio.edu/cleng_facpub

Part of the Literature in English, British Isles Commons

How does access to this work benefit you? Let us know!

Publisher's Statement

This is a pre-copyedited version of an article accepted for publication in Criticism: A Quarterly for Literature and the Arts, Vol 48, Issue 3, Summer 2006 following peer review. The definitive publisher-authenticated version is available from Wayne State University Press.

\section{Recommended Citation}

Sonstegard, Adam, "Performing Remediation: The Minstrel, The Camera, and The Octoroon" (2006). English Faculty Publications. 16.

https://engagedscholarship.csuohio.edu/cleng_facpub/16

This Article is brought to you for free and open access by the English Department at EngagedScholarship@CSU. It has been accepted for inclusion in English Faculty Publications by an authorized administrator of EngagedScholarship@CSU. For more information, please contact library.es@csuohio.edu. 


\section{ชิธ}

\section{$\begin{array}{llllllllllllll}A & D & A & M & S & O & N & S & T & E & G & A & R & D\end{array}$ Performing Remediation: The Minstrel, The Camera, and The Octoroon}

ON THE EVE OF THE first conflict America would wage in part with photographic images, the first actor to play a photographer debuted on the American stage. He took his place alongside the antebellum era's minstrels, Shakespearian actors, and imitators of Jenny Lind, and enticed the play's other characters to pose for their portraits. His camera recorded one character's murder of a character in blackface; his apparatus got smashed to pieces by a character dressed as an Indian brave; and a photograph, found within his apparatus, came to "prove" the murderer's guilt. With the opening of Dion Boucicault's drama The Octoroon at New York City's Winter Garden Theater in December 1859, photography made a remarkable American theatrical debut.

During that debut, one medium, a stage performance, including minstrelsy and playing out before an audience, participated in constructing another medium, photography. As the play dramatized it, photography could ascertain the identities of individuals otherwise understood to be ambiguous, as both guilty and innocent, black as well as white, one of "us" and yet one of "them." Photography could help establish some of these identities, like tragic mulattos, as essential and biological; and other identities, like blackface minstrels, as superficial and performative. It could document the performance of criminal acts, subsequently identify or incriminate the performers of those acts, and establish "the truth" behind the criminals' false claims or pretenses. The Octoroon included photography as a dimension of theatrical illusion, as it made photography coextensive with the conventions of minstrel performance, and had it accord with the identities that players assumed onstage as theatrical roles. And yet the play understood photography to dispel illusions, as it constructed photography's capacity to expose facts beyond staged performances, and relied on its supposed ability to reveal criminals' "true" selves, beyond their assumed identities. Photography could form a part of this 
staged performance, and yet reveal "truths" that lay beyond the merely apparent and consciously performed.

The Octoroon in fact explores what aspects of photography can and cannot be staged, and in turn, what aspects of the stage can and cannot be photographed. This drama and its audiences thereby bring about a fascinating moment in the unfolding history of the representation of evidence and "truth" in these two representational media. One can use such a moment to judge the capacity of a new, developing medium to produce and circulate truths, relative to the capacity of an older medium to present and maintain them. One can understand such a moment as an instance of what Jay David Bolter and Richard Grusin have termed "remediation," "the representation of one medium in another." The Octoroon constitutes one of the earliest instances of remediating photography, representing it, as a medium, within the already established media of stage performance and minstrel comedy. "Our culture conceives of each medium or constellation of media as it responds to, redeploys, competes with, and reforms other media," explain Bolton and Grusin, who are, in their words, "offering a genealogy of affiliations, not a linear history, and in this genealogy, older media can also remediate newer ones." "The drama in these respects pits the performed pretenses of the stage, with its conventions of minstrel comedy, against photography, with its claims to naturalized, authenticated truth. The media compete as one represents the other, with theater testing photography's capacities and claims, relative to its own. The Octoroon even has the remediated medium resolve the dramatic conflict of the play, "proving" the murderer's guilt, which the primary, performative media cannot resolve by itself. In this play, then, theatrical performance looks to the "truths" photography can establish, beyond what theatrical performance can.

Noted by theater historians but omitted from critical histories of American photography, ${ }^{2}$ taken up by performance theorists, but neglected in theories of visuality, ${ }^{3}$ The Octoroon "stages" and performs one of photography's first remediations in American theatrical history. As such, it portends the eventual ascendance of mechanical media, such as photography, over performative media, such as theater and minstrelsy. It anticipates audiences who will come to prefer photography's and cinematography's naturalized "truths," rooted in supposed authenticity, to theater's performances, based on minstrel conventions. As members of such audiences, twenty-first-century American readers imagine stage productions of The Octoroon in ways that are mediated by their own experiences with photographic and cinematic media. The play represents an important historical moment, at which Americans first moved toward naturalizing photography's role in surveillance; an analysis of the play today dramatizes, as it were, the extent to which Americans have accepted-indeed, have become saturated with-that very culture of photographic surveillance. Boucicault and the theatrical players had to coach audiences in 1859 to accept photography's role in resolving the conflict of this play; modern readers, because they have been 
absorbing such coaching from photographers all their lives, find it difficult to imagine this drama playing out any other way.

\section{Identity and Photography}

Known for both acting and directing, and already noted for the success of London Assurance (1841), Dion Boucicault not only wrote and directed The Octoroon, but also built the Midtown Manhattan theater, the Winter Garden, where it debuted. He even cast himself and his wife, Agnes Robertson, in starring roles. ${ }^{4}$ An Irishborn thespian who had won acclaim from immigrant and "native" audiences, Boucicault represented African-American slaves in The Octoroon's plantation setting. He opened the play within days of John Brown's execution, directly addressing the charged political climate of December 1859. Comparisons with the many stage dramatizations of Uncle Tom's Cabin were inevitable. Overlap with blackface minstrelsy, thriving in multiple venues, was to be expected. ${ }^{5}$ The play's articulation of the one-drop rule, its onstage representation of a slave auction, and its love affair between a white man and an octoroon slave, were calculated sensations. ${ }^{6}$ By 1859, Boucicault had clearly become an accomplished, resilient architect of theatrical illusions.

By 1859, American photographers also depicted themselves as both architects of illusion and providers of an important system of identification. First appearing twenty years earlier in the form of daguerreotypes, photographic technology by this time had proliferated into landscape images, commercial portraits, and visual calling cards called cartes de visite. Photography in all of these forms carried the potential of a democratizing medium. The photographic image was the "card of introduction," wrote one authority, "to make all mankind acquaintances."7 With an inexpensive portrait, commented another authority, "the humblest chamber-maid can today send her lover as true a likeness as a duchess can have at her bidding." ${ }^{8}$ The expense of oil painting had reserved portraiture for aristocratic patrons of the arts and made the canvas the exclusive domain of the wealthy and ruling classes. But the accessibility of photographic studios brought portraiture to the masses, so that Civil War soldiers were likely to have cartes de visite of their fiancés, families often possessed miniatures of children whom they had lost in epidemics, and the public frequently recognized the faces of wanted criminals from circulated photographs. As the first major advance in representational technology since America's founding as a democracy, photography provided a more democratic access to portraiture than middle- and lower-class citizens had ever before enjoyed.

As it promised to offer a greater number of sitters more democratic access, it also offered viewers unprecedented access to the supposed truths of the sitter's inner being. One authority wrote that, thanks to photographers, artists working in conventional media "have been constrained to present not merely the exact 
lineaments, facial and figural, of their subjects, but also what is vastly more important, that expression which reveals the mind-the heart-the individualizing soul of the same." "When Walt Whitman described a daguerreotype gallery, he recorded a "strange fascination," "a sort of magnetism" he felt around portraits: "An electric chain seems to vibrate," he wrote, "between our brain and him or her preserved there so well by the limner's cunning. Time, space, both are annihilated, and we identify the semblance with the reality-And even more than that. For the strange fascination of looking at the eyes of a portrait, sometimes goes beyond what comes from the real orbs themselves." ${ }^{10}$ Portraits not only revealed truths, but also showed especially attuned viewers inner secrets, which they could not glimpse by any other means.

Nathaniel Hawthorne, for his part, described seeing himself for the first time in a photographic negative, and recorded "a perception, for a moment, of one's eventual and moral self, as if it were another person - the observant faculty being separated, and looking intently at the qualities of character. There is a surprise when this happens - this getting out of one's self, - and then the observer sees how queer a fellow he is." "ll Seeing himself in a new way, Hawthorne discerns visible signs of morality and destiny. Photographic portraits seemed to reveal more about the sitter's inner personality, to "vibrate" more, in Whitman's terms, with the viewer's perceptions, than faces did without the aid of photography. Disclosing traits that had been hidden, even to sitters themselves, photography recorded outward appearances, as they provided indices of inward souls and psyches.

Photography posed as an index of character because its practitioners surrendered agency to the natural medium of sunlight. The sun's rays etched the subject's aspect on the daguerreotype's surface, copying subjects "as they really were," and preventing photographers from shaping the result. Oliver Wendell Holmes, for one, assured his readers that "attitudes, dresses, features, hands and feet, betray the social grade of the candidates for portraiture. The picture tells no lies about them. There is no use of their putting on airs; the make-believe gentleman and lady cannot look like the genuine article."12 The same idea, phrased even more chillingly, emerged from Marcus Aurelius Root's 1864 treatise on photography: "In vain do the profligate, the base, and the selfish mimic those outward indications which pertain naturally to the pure, the good, and the generous," Root warned. "Men shall ultimately be known for what they are . . Inward unworthiness, despite all effort, will glare through the fleshly mask."13 Appearances inevitably shadowed essences, enabling the camera to expose a guilty subject, identify a soon-to-be guilty vagabond, or make a sitter's innocence manifest. Early authorities placed great faith in photography's abilities to secure "the genuine article," and to separate imposters and pretenders from society's "authentic" ladies and gentlemen. Democratically, the new medium first granted those with less wealth and lower social standing access to portraiture; revealingly, it purported to bring out the inner nobility of moral character, whatever the sitter's rank. 
These ideas about photography take hold in Terrebonne, The Octoroon's Louisiana riverside setting, before the play's action begins, when Salem Scudder arrives from the North, and becomes the region's first aspiring photographer. Scudder's artistry with the camera, Northern origins, and status as a Yankee stock character or stage stereotype all complicate his characterization. Scudder's Northern background allows him to stand in a long line of nineteenth-century stock figures, known as Yankees and commonly called Jonathan or Adam. Such Yankees could often appear as rubes or bumpkins, who lent comic relief for their folksy simplicity and lack of sophistication. Their simple honesty often contrasted with foreign characters' effeminacy or social climbers' fastidiousness. Scudder's Northern origins also mean he is an outsider to Terrebonne, who joins the widowed Mrs. Peyton and her nephew, George Peyton, who has recently returned from a wild youth as a ladies' man in Europe. Scudder narrates his history to George, and mentions he had once been an inventor. "He cut that for the photographing line," Scudder says, speaking of himself in the third-person. "He and his apparatus arrived here, took the judge's likeness and his fancy, who made him overseer right off. Well, sir, what does this Scudder do but introduces his inventions and improvements on this estate." ${ }^{14}$ Having photographed Judge Peyton, Mrs. Peyton's late husband, when he first arrived, Scudder decides early in the play to photograph Dora Sunnyside, heiress of a neighboring plantation. As she smiles and enjoys the photographer's attention, he explains "the machine can't err. You may mistake your phiz but the apparatus don't." If a sitter says of her portrait, "But, sir, it ain't agreeable," the photographer replies, "No, ma'am, the truth seldom is" (110). As was often the case, the woman sat for the photographer; he "captured" her image; and then he coyly claimed its success was out of his hands. As a Yankee stock character, Scudder could embody rustic simplicity and speak a native truth that contrasted with fastidious, foreign ways. As a Northerner, he could stand apart from the social classes of Terrebonne. And, as a portraitist, he could also import photographs, "inventions and improvements." He depicts wealthy subjects. He claims photographic objectivity. He lives alongside the Peytons-who, with no rightful heir and with an ominous record of financial mismanagement, comprise the fading gentry of Terrebonne.

Aspiring to the gentry's status, but lacking their manners, Jacob M'Closky manages the plantation's slaves as he attempts to ascend its social ranks. "Curse their old families," he soon says of the Peytons and Sunnysides, "a bilious, conceited, thin lot of dried-up aristocracy." "Just because my grandfather wasn't some broken down Virginia transplant, or a stingy old Creole," he snarls, "I ain't fit to sit down to the same meat with them" (113). In a commingled world of transplants and Creoles, the aristocrats conceal their contempt and the slaves obey. But M'Closky's condescension, Irish ethnicity, and slave master's sadism exclude him from Terrebonne's social circles.

The remaining classes, anchoring this social order, encompass the comic slave boy Paul and the laughing "old darkey" Pete, but also include Zoe, the play's 
title character. The offspring of Judge Peyton and a quadroon slave, Zoe the octoroon was freed by the Judge on his deathbed. ${ }^{15}$ Legal snarls complicate her manumission, and leave her vulnerable to slave-traders. She appears lightskinned, she acts genteel, and she soon attracts George Peyton's love interests. Zoe has assumed that George feels love for Dora Sunnyside, and merely a strained, polite affection for herself. She is shocked when he reveals he loves her instead, chagrined when she must reveal she is an octoroon, not the white heiress he takes her to be. She must, in Mark Mullen's words, "teach George how to read her body." 16 "Do you see the hand that you hold?" Zoe begins, looking into his eyes; "Look at these fingers; do you see the nails are of a bluish tinge? . . Look in my eyes; is not the same color in the white?" Each of these features, she explains, bears "the same dark, fatal mark — the ineffaceable mark of Cain" (111-112). Zoe places herself within a tradition of tragic mulatto heroines, whom viewers would have recognized from Xarifa in Lydia Maria Child's short story "The Quadroons" (1842), from Cassie in Harriet Beecher Stowe's Uncle Tom's Cabin (1852), or from the title-character of William Wells Brown's Clotel, or The President's Daughter (1853). Zoe speaks of African-American blood, the supposed one-drop rule, and the curse of Ham. She declares herself "an unclean thing, forbidden by the laws," explaining finally, "I'm an octoroon!" (111-112). Her identity, as performance theorists have pointed out, is determined by her "dark, fatal mark," despite her fair complexion. ${ }^{17}$ It is "written on her body" as biological fact, even as it requires her performance as naturalized condition. ${ }^{18}$ It is spelled out for George, the white, male observer, even as it renders Zoe an "object" that is not human-an "unclean thing" — that is thereby not assigned a gender. ${ }^{19}$

These readings highlight Zoe's identity as a tragic mulatto, but tend not to consider her in relation to minstrelsy and photography, which also work to classify racial identities in the play. The conventions of minstrelsy, long in place by the late 1850s, still dictated the appearances and behaviors of the play's other AfricanAmerican characters. ${ }^{20}$ Actors who dramatized these characters applied burnt cork to their complexions, to affect a supposed racial marker. They sang and danced according to accepted conventions, to enact a Northern, romanticized rendition of "blackness." Eric Lott sees "the eternal and predictable return of the racial signifier of blackface ... occur[ring] when the lines of 'race' appear both intractable and obstructive, when there emerges a collective desire (conscious or not) to bridge a gulf that is, however, perceived to separate the races absolutely." ${ }^{21}$ Minstrels stayed within accepted boundaries, reassigned their own perceived shortcomings to people who occupied lower social strata, and invested working-class "whiteness" with virile masculinity — all within a culture they perceived as classist and emasculating. Minstrelsy pretended to dissolve class difference among whites engaged in performance, even as it excluded subordinated blacks from that performance. ${ }^{22}$

The Octoroon took these established conventions of blackface minstrelsy and combined them with relatively new discourses of hybridity and photography. 
Grossly exaggerated lips and superficial burnt-cork coloring marked one kind of "black" in the play; Zoe's nails and eyes, her white complexion, supposedly marked another kind. One way of thinking constructed race as a layer of burntcork coloring, as a way of acting, a performance enabling comedy; another way, emerging on the same stage, regarded race more profoundly, as a way of being, a condition initiating tragedy. Minstrel characters, Eric Blair notes, "redrew the race line larger than life in indelible blackface pencil, ... serv[ing] the political world" of the late antebellum period "by definitively laughing blacks out of serious consideration." The minstrel show's construction of "the black as irremediably Other consolidated the political world of whites of whatever stripe."23 Minstrelsy collapsed complicated gradations of "race" into a facile dichotomy, letting every shade on one side of that supposed line celebrate common bonds. But octoroons redrew it as a perilously fine line, trapping some figures in a tragic intermediacy. Sadiya Hartman remarks that Tom's suffering in Uncle Tom's Cabin "proclaimed his saintliness" and Zoe's travails in The Octoroon similarly "conveyed her great love and humility," even as "black characters bearing a striking resemblance to Zip Coon, Jim Crow, and Coal Black Rose, the bumbling, loyal, and childish Sambos and wenches of minstrel fare, provided the comic b(l)ackdrop of virtue's triumph." ${ }^{24}$ A slave's wounds and a mulatto's misfortunes bore witness to blacks' status, but burnt-cork coloring and exaggerated antics also parodied that status. The play spoofed "race" with obviously staged minstrelsy, but it also posited that "race" was a body's inherent condition, separate from its conscious performances. It encouraged whites to laugh in camaraderie at the antics of racial Others, but it also suggested that some of those who laughed might "really" be Others. They might even be exposed as octoroons.

As the play carefully keeps Zoe's octoroon identity separate from the other characters' minstrel identity, it also keeps her distant from the identities constructed in part by Scudder's camera. Zoe constructs her racialized image as she teaches George to read her body, but she does so while cameras are nowhere in sight. Audiences know that George feels enough affection for her to make her his wife; but they do not know, until Scudder confesses it later, that he also harbors secret affections for her. Neither suitor woos her or flatters her with a daguerreotype. It seems just as crucial that Zoe is never photographed, as it is that Dora Sunnyside is photographed: the silent exclusion of Zoe, the outcast hybrid, and the insistent inclusion of Dora, the white heiress, illuminate photography's negotiations of this antebellum plantation's social strata. If photography were truly a democratic medium, as its promoters held it to be, it should serve to highlight someone as distant from the established Southern nobility as this "lowly" hybrid slave. If it could truly emphasize inner traits of character, as advocates said it could, it should bring out Zoe's nobility within.

Photographers who sought to depict plantation families in fact excluded certain elements from the picture frame. Slaves register in photographic records 
most often as evocative absences, conspicuous omissions from official family records. Even the figure of a slave "mammy" or nursemaid, Laura Wexler tells us, had to remain absent from the picture. "Photographing the 'nursemaid' threatens to alter the balance of power between" what Wexler calls established "facts' of sentiment and hidden others. It threatens to give her a social currency, as an outsider inside the home, that she should not have." ${ }^{25}$ An image of a "mammy" would inform observers that an African-American woman had raised and suckled the plantation's white children. An image of Zoe would suggest that an African-American woman had not only raised, but had given birth to this plantation's children. If Zoe did not remain in the background of Terrebonne's portraits, she would represent testimony that her mother had not remained in the background either, had not stayed "outside" the Peyton family. If Scudder pictured Zoe, he could damage his reputation as a photographer, or harm their reputation as a family. It is difficult to determine Scudder's degree of agency over his camera, but he knows to aim it toward plantation owners and heiresses, and away from outcast octoroons.

That the camera takes its place on the same stage with the identity that Zoe constructs with racial rhetoric and corporeal signs, and the identities that others construct with comic behavior and cork coloring, reveals the play's delicate social machinery. It constructs African-American identity as a comic matter of minstrel performance; yet it also makes mixed-race identity a tragic component of Zoe's natural condition. It features minstrels who apply coloring to create crude racial masks; yet it also engages with photographic theory, which ensured that "inward unworthiness will glare through the fleshly mask." ${ }^{26}$ Theater, featuring minstrel performance, remediates photography, promising "truths" beyond performance. Media with inconsistent ideologies compete within the same theatrical production. If the camera in this play should fall into the wrong hands, it could point up these ideological contradictions. It could highlight something other than plantation Louisiana's social ideals. It could betray some of the subtler "truths" the Peytons choose to keep concealed.

\section{Performance and Possession}

As Boucicault's delicately ordered theatrical world follows in the established traditions of melodrama, Scudder's camera does indeed fall into strangers' hands. Dora, who feels flattered, poses for the camera, while two unlikely observers express their doubts. One of them, Paul, an actor in blackface playing a happygo-lucky slave boy of thirteen, says of the sitter, "She looks as though she war gwine to have a tooth drawed!" (110). The second, a Native American adult, Wahnotee, played by Boucicault himself, sees the camera as a magical device that records people's physiognomies as it steals people's souls. Paul allays his fears, and decides to take his own picture after Dora and Scudder leave the scene. "I 
must operate and take my own likeness too," he explains; "how debbel I do dat?" He tries to be both photographer and sitter, walks around the device in comic perplexity, and muses, "Can't be ober dar an' here too. I ain't twins" (112). He cannot be photographer and sitter, subjective operator of a camera and object of the camera's gaze, all at once. But notice that he can exist within two systems of representation simultaneously: as a character with a camera, he could embody the potential to create his own representations. But as a white actor appearing onstage in blackface, he also serves as a reminder of whites' exclusive power over the representation of blacks. Conflicting systems of representation, minstrel performance and photographic identification, which uneasily coexist within the same drama, threaten briefly to coincide within the same character.

This threatened reversal of the camera's representational powers coincides with the many reversals of the melodramatic storyline. Zoe finds that spurning one suitor, George, means drawing another one nearer, for M'Closky, the scheming Yankee slave-owner, aims to make her his concubine. M'Closky discovers that a legal suit, which Zoe's father left pending when he died, nullifies his manumission of Zoe. The Judge never legally freed her, and never secured the deed to the estate, so only one obstacle prevents M'Closky from owning both the lady and the parcel of land: a financial settlement that a Liverpool firm owes the Peytons. The Judge's widow, who expects that settlement to arrive in the mail, plans to use it to buy back the estate, so she sends Paul and Wahnotee to intercept the mailbags by the riverside, where Scudder had left his camera. They play with the camera, resuming their efforts to take Paul's picture-until M'Closky arrives and catches Paul with the mailbags. Failing to see the camera, M'Closky sweeps down on Paul.

M'Closky murders Paul. The audience witnesses the act. The camera captures the deed. As the picture develops, M'Closky miraculously retains his posture atop the mailbags, reading a letter he finds in the mail and discovering that the Peytons do indeed stand to gain thousands from the Liverpool firm. When Wahnotee returns, M'Closky hides the letter and conceals himself, but fails to notice Scudder's apparatus, as Wahnotee gathers that the apparatus has murdered Paul. Unaware of the circumstances of Paul's death, the Indian smashes the camera to pieces; unaware for now that the camera has captured an image, the audience observes its destruction. The camera witnesses these reversals of fortune, becoming the first of three objects to fall into strangers' hands.

The second "object" to do so, under similarly tragic circumstances, is Zoe herself. M'Closky comes to own Terrebonne, and auctions off its slaves, including Zoe. In the play's most famous spectacle, she stands on a table, suffers M'Closky and George to bid for her, and draws sympathy from the others who wait to be auctioned. Understood to be a salable quantity, an item for a suitor to bid upon, and implicitly an "object" for the sexual exploitation of the highest bidder, Zoe comes to occupy complexly divided ontological categories. ${ }^{27}$ The play shows her to be a breathing person, and yet subjects her to a social system that 
makes her an "object" for others to possess. It shows her to be a seemingly white woman, who displays none of the obvious, blackface signs with which Southern ideologies would construct her in turn as a salable quantity. The audience does not share M'Closky's designs, but still fights in a way for possession of Zoe. As M'Closky wants her as a slave, and George wants her for a wife, the audience also wants to take her-for granted—as an object for their facile empathy. ${ }^{28} \mathrm{M}$ 'Closky wins the fight, coming to own Zoe and Terrebonne.

As a simple prop within the storyline of the play, similar to Desdemona's handkerchief, the camera facilitates these melodramatic reversals in the drama's action and in the characters' fortunes. It can provide a flattering portrait for one character, Dora, but it can also provide an incriminating piece of evidence against another character, M'Closky. It can function as a device for creating representations, enabling photographers like Scudder to become culturally empowered portrait-artists. But it can also be an object possessed by others, resembling slaves like Paul or Zoe, who become subject to others' ownership and objectified in others' representations. Cameras, octoroons, and plantations- "objects" to be possessed in the play's patriarchal world—fall into the hands of relatively wealthy, Caucasian men, agents who are capable of their possession.

Though Scudder, Paul, and Wahnotee can possess cameras, M'Closky can possess Zoe, and M'Closky can possess Terrebonne, only the camera possesses evidence of Paul's disappearance. Paul becomes a missing person just before the auction, and attracts unwanted scrutiny. Perpetuating a stage stereotype, Wahnotee reappears, acting as a drunken and belligerent Indian. Soon almost all of the players call for lynching Wahnotee. But as they discover him, they also locate the smashed camera, with a photograph still inside: "Here's a pictur' I found stickin' in that yar telescope machine, sir!" says the "old darkey" Pete. Scudder has the first look at the new photograph.

"Jacob M'Closky," Scudder immediately declares, "you murdered that boy!" He hastily makes his explanation to the incredulous company:

You slew him with a tomahawk; and as you stood over his body with the letter in your hand, you thought that no witness saw the deed, that no eye was on you - but there was, Jacob M'Closky. The eye of the Eternal was on you; the blessed sun in heaven, that, looking down, struck upon this plate the image of the deed. Here you are, in the very attitude of your crime. (121)

With the authority of the "eye of the Eternal," emanating through the camera itself, the men convene a kangaroo court. They make the questionable assumptions that they comprise a proper jury and that the camera provides sufficient evidence; M'Closky alone disagrees. The men reject his dissent. They accept the image as evidence. They ignore their self-interest in removing him from their midst. 
Their unanimous decision to convict M'Closky grants the camera special status as it initiates the drama's final melodramatic turns. The accused escapes to the river. He boards a boat to elude the jurors. A vengeful Wahnotee follows, and presumably apprehends him, just as a spectacular riverboat fire breaks out onstage and draws away the audience's attention. The jury members then recover the letter from the lawyers, and tell Mrs. Peyton of the financial windfall that will allow her to regain Terrebonne. As this transpires, Zoe borrows a bottle of poison from another slave's supply. She imbibes it, and lives just long enough for George to rush to her side with news of the conviction, the financial windfall, and the riverboat fire. "Let me look at you," she says to George, "that your face may be the last I see of this world. O! George, you may, without a blush, confess your love for the Octoroon!" (125). Only with Zoe's death can George speak unabashedly of interracial affection. Only with M'Closky gone can others continue to live on Terrebonne. Only with the camera's evidence can anyone convict the villain of the piece.

\section{Evidence and Authenticity}

If indeed "the very idea of what constitutes evidence has a history," as John Tagg has suggested, ${ }^{29}$ this last act is replete with historic moments. The staged photograph proves exceptional in that it catches M'Closky in the act of committing a crime, rather than revealing M'Closky to be the kind of person to commit it. "On the assumption that a natural predisposition toward certain forms of behavior would be apparent on the surface of the body so disposed," Nancy Armstrong notes, "Victorian social scientists took to photographing the faces and bodies of criminals, whores, the indigent, the homeless, and mentally disturbed individuals, hoping to identify the visual signature of their social pathologies." ${ }^{\text {"30 }}$ Oliver Wendell Holmes, for one, had furthered the idea of a "rogues' gallery," in which the police could recognize the habitual facial expressions of men deemed likely to commit crimes. Rogues' galleries would document "what the faces of the most hardened criminals have in common," since "all of the villainous looks have been shaped out of the unmeaning lineaments of infancy." 31 "Visual signatures" or facial "lineaments" supposedly denoted innate criminal capacity.

In Boucicault's play, M'Closky is caught in the act, not by betraying the inclinations of a likely murderer, or showing himself to be identical to a known suspect, but by striking a pose, "the very attitude of [his] crime." The camera records his posture and performance in committing an act, rather than identifying a potential performer of such an act. Given the necessarily long exposure times and the cumbersome apparatus, spontaneity remained out of antebellum photography's reach. But Boucicault adapts it to performance, offering innovative surveillance. The Octoroon already blurs important distinctions, between being an octoroon because of "blackness" within, and "acting" black because of a "blackness" made from burnt-cork coloring without. Now it dissolves additional social 
distinctions, between being a villain (exposed and identified as a murderer), and "acting" or performing like one (being caught committing the criminal deed). Jennifer Green-Lewis has determined that "the much touted 'democratizing principle' of photography was not, after all, a promise that all trees or buildings might be rendered equal in aesthetic terms; it was a threat that photography could destroy social differences between sitters." 32 The Octoroon dramatizes, to a greater extent than any other known antebellum document, photography's potential to dissolve these social distinctions. What separates "us" from "them," the play veers close to suggesting, might not be a way of being, a biological difference within. It might instead be a way of acting, a superficial and conscious performance. This state of affairs might only last until "they" start looking and acting like "us." Or, even worse, until one of "us" — carelessly, scandalously_-starts acting like one of "them."

At the same time, the play constructs photography to support the idea of an objective, disinterested vision through the camera—despite evidence within the play of vested interests. Harley Erdman has remarked that Boucicault "grounds his discourse in the 'it' of the apparatus, as if the processes involved in framing, exposing, and developing pictures took place without the intervention of a human hand." 33 "It," the camera, did the work, while "I," the photographer, did not shape the results. The "eye of the Eternal" always guides the apparatus, so anyone could take a photograph. Anyone who viewed that photograph glimpsed the same truths.

That the play understands the "truths" of photography to emanate from the Divine "eye of the Eternal," and not from the subjective frame of reference of any mortal man or woman, places Scudder's camera in line with the model of the camera obscura, and complicates Jonathan Crary's account of photography's historical development. Designated by the Italian phrase meaning "dark chamber" or "dark room," the camera obscura is sometimes regarded as photography's eighteenth-century forerunner or prototype. Crary has demonstrated that photographic technology in the early nineteenth century began to shift away from the original model provided by the camera obscura. This model permitted viewers a single, fixed point of entry — an aperture in the side of the "dark chamber" — for looking at the subject matter inside. The viewer's frame of reference seemed predetermined or even ordained by the placement of the aperture, and not affected by the individual viewer's conscious choices of where to look or how to position his or her body in the act of looking. The camera obscura seemed to grant a "God's eye view"- - a predetermined frame of reference, aligned with classical perspective-rather than an opportunity for the individual observer to alter his or her perspective at will. According to Crary, the camera obscura became obsolete soon after 1800, when its "linear optical system, its fixed position, its categorical distinction between outside and inside, were all too inflexible and unwieldy for the needs of the new century." 34 Observers needed a way of thinking about vision as 
manipulable, a "way of seeing" that did not correspond with traditional perspective, with its supposed "God's eye view," but that took into account who observed whom, how the observer angled her vision, and how she positioned her body as she observed.

This play, then, is one of the exceptions to the trend Crary traces, in which photography departs from the visual mode of the camera obscura and classical perspective. In the play, the camera's vision operates from a vantage point beyond that of any embodied observer, as is the case with the fixed frame of reference of the camera obscura. It is not constructed to align with any individual character's subjective or corporeal point of view, as would be the case if the play's camera departed from classical perspective. Scudder has abandoned the camera, Paul fools with it but cannot take his picture because he "ain't twins," and M'Closky never knows it is there. It remains in doubt whether the photograph is even a white-authored image; no one-"red," white, black, or octoroon-can or must claim authorship of the picture. Aided by the "eye of the Eternal," it is free of any character's vested interests. Blessed with the very sunshine of objectivity, it automatically "frames" the villain. Independent of any individual's body position or subjectivity, it grants classical perspective's "God's eye view." Convicting M'Closky and resolving the dramatic conflict, it affirms the audience's belief in the "truth" of the crime. Though theater and minstrelsy remediate photography in The Octoroon, this photograph seems to emerge unmediated from the drama itself.

\section{Media and Remediation}

This last section begins by taking a step back from Boucicault's staged spectacle, to try to picture: African-American characters who were in fact Anglo-American actors wearing blackface; a Native American character who was not really an Indian, but Boucicault himself, starring in his own drama; a heroine who was not really an octoroon, but Boucicault's Caucasian wife; one character's act of murder that was not really a killing, but a staged event without bloodshed; a photographic apparatus that was not really a camera, but a prop that could be smashed, restored for the next show, and smashed again; an image that was not really a photograph, but a prop that only a small portion of the theater audience could see; an accused murderer who was not really a killer, but a player tried by others, and restored to innocence for the next showing. Audiences knew which "truths" the photograph in the play revealed-but only according to the truths the play prompted them to accept. They knew to take what the camera told them as unconstructed truth-but only within the very constructed truths that Boucicault's players told them all along.

The play assures audiences they can trust the proof that their own eyes witness, and that the camera verifies. But all along, the story coaches them to accept 
certain conventions as truths, to reject certain others as mere appearances. It coaches them to accept the camera's images as something entirely separate, as something with a greater claim to "truth" than the theater's claim, for the camera's mechanical, automatic means, as opposed to a human being's consciously performed, inevitably subjective means, of recording "truth." It prompts audiences to hold the "truth" the camera reveals to them above the "truth" the theater performs for them. It gets them to forget that this photograph is not actually separate, but a portion of this staged performance. It performs photography, as if photographic truths were never performances, but authentic, unperformed, and "real." The Octoroon stages photography—as if photography could not possibly be staged.

The photograph of M'Closky — a representation embedded within a theatrical performance, and yet constructed as more authoritative than the performance, of which it forms a part-is highly mediated, or what Bolton and Grusin would term "hypermediated." But the play makes it seem transparent, constructing it as coextensive with the audience's own vision of Paul's murder. "Hypermedia and transparent media are opposite manifestations of the same desire," Bolton and Grusin explain: "the desire to get past the limits of representation and to achieve the real. They are not striving for the real in a metaphysical sense. Instead, the real is defined in terms of the viewer's experience: it is that which evokes an immediate (and therefore authentic) emotional response." 35 Seemingly unmediated, photography transparently provides unimpeachable evidence. Evoking what feel like authentic responses, photography succeeds more than other, more manifest media-like the obvious conventions of minstrelsy, the artificiality of melodrama-because of its own self-erasure. Photography could erase the traces of its own interventions in performances, leaving viewers with the impression they had glimpsed supposed eternal truths for themselves.

Theater, then, in remediating photography, discovers photography's broader capacities. Staged performance still overtly consisted of one playwright's enacted vision, one cast's elaborate performance, and one race's blackface representations of another, all visibly performed for the viewer. But photographic artifice could become invisible to audiences: it could erase its own biases and interests, and appear "natural," as it credited the audience's vision as truth. Photography enabled free-play that dissolved social distinctions, flattered egalitarian American ideals, and made the democratic suggestion that anyone could take a picture, and anyone could be pictured. Photography made it easier to forget that in most cases, enfranchised, white hands held the cameras; that disenfranchised, non-white bodies were left to pose (or forced to pose) before them. It superseded more obvious facts about minstrelsy: that white, male faces most often wore the masks; that female and/or non-white identities were the ones derided or lampooned; that even in an art form thought to dissolve whites' socioeconomic differences, only certain performers were licensed to mimic others. In contrast to photography, as the play constructed it, minstrelsy seemed more exclusionary in 
its politics of "race" and class, more patently artificial, and more overtly constructed in performance.

The photograph in this play in the late 1850s in fact has less in common with the minstrelsy that remediates it, than it does with the cinematography of the late 1890s, which the photograph in this play prefigures. Boucicault's spectacles, from M'Closky's murder to the riverboat inferno, heralded similar spectacles in photoplays, the first sets of photographs to be assembled onto reels and projected onto screens, thereby giving the illusion of motion pictures. Audiences of these early motion pictures would see spectacles in drawn-out scenes, occasionally interspersed with a caption or line of dialogue, which appeared as text on the screen. Such scenes would recall Boucicault's elaborately staged spectacles and their sustained appearances before theater audiences. Boucicault's conventions of melodrama and improbable, instantaneous reversals of characters' fortunes would also carry over into early cinematography. The exaggerated pantomime that actors in photoplays performed, as they carried meaning to audiences without the aid of sound, would also appear akin to Boucicault's variety of overacted onstage melodrama. ${ }^{36}$ Though Boucicault's audience could not have known it at the time, the play's spectacles, melodrama, and utilization of a still photograph to "frame" a murderer, all foreshadowed later, cinematographic technology's sustained spectacles, seemingly overacted pantomime, and illusion of moving pictures. The Octoroon portends the ascendancy of photographs and photoplays, and begins to relegate theater itself to a lesser role in American culture. There, theater could "merely" perform the "truths" that photography and eventually, cinematography could be taken to authenticate and "prove."

This is not to claim that Boucicault could foresee the course minstrelsy followed after 1859. Eric Lott traces minstrelsy's "partial absorption into the Uncle Tom's Cabin melodramas" and its process of "settling into a rather lifeless, and enormously profitable, institutionalization" by the time of The Octoroon. ${ }^{37}$ Henry B. Wonham, for his part, determines that "ethnic images migrated from the declining minstrel stage to the pages of America's burgeoning magazine industry," and that "as minstrelsy's public spectacle yielded to the more private experience of ethnic caricature in novels and magazines, the images themselves developed in response to a new set of anxieties, including unprecedented fears about immigration, miscegenation, and 'race suicide."'38 Minstrelsy's late-nineteenth-century fate still seems contested.

In Boucicault's case, these alarming new concerns for whites demanded photography and film as reassuring media. Photography flattered viewers' biases, while asserting that racial differences emanated from the "eye of the Eternal," and not merely from an actor's performances or a director's preferences. It facilitated the free-play of egalitarian access to photography as a medium for all "races" and classes. It presented racial differences between them, not as mere matters of performance, but as naturalized truths. Allowing viewers the fantasy of performative 
identities, photography erased the traces of that fantasy's construction. Prompting observers to accept photographed performances as unmediated truths, it obscured photographers' roles in arranging the pictures and posing the sitters. Suggesting that the racial markers that audiences perceived were inherent, biological truths about the observed, it denied that such markers could in fact be side-effects of observation. Even as this overtly theatrical, melodramatic performance remediated photography, photography outperformed performance.

In turn, modern readers encounter Boucicault's drama, and imagine its stage production, in ways that are mediated by their own experiences with cinematographic technology. Gone With the Wind (1939), Guess Who's Coming to Dinner (1967), and Guess Who (2005), respectively, have broached, legitimated, and spoofed the topic of interracial relationships on film. This makes it easy for modern readers to suppose that African Americans filled the roles of blacks in The Octoroon, and easy to forget blackface as the period's medium for representing race. A modern understanding of the on-screen depiction of interracial relationships obscures an important dimension of identity for the historical play's Angloand Irish-American cast. Modern television speaks of shows "taped before a live audience." This makes it easy for readers to discuss The Octoroon in terms of a "live" production, in contrast to the photograph that is taken as that production progresses. "Prior to the advent of [such] technologies (e.g., sound recordings and motion pictures)," Philip Auslander warns, "there was no such thing as 'live' performance, for that category has meaning only in relation to an opposing possibility." ${ }^{39}$ To call something "live" presupposes something else that is reproduced, some medium to furnish the reproduction. It is easy to forget that this play is only acting as if something has been reproduced. Its supposedly reproduced image, in which M'Closky murders Paul, is part of the "live" performance. It is a product of the older, stage medium. Though recording sound, splicing film, and burning compact discs encourage modern audiences to think of "the recorded" and "the live," it is anachronistic to speak of both kinds of media in The Octoroon.

Finally, when Zoe supposedly reveals her racial markers to George, it is easy to read the moment, as it would be mediated by more recent historical advances in film technology. As Jennifer DeVere Brody points out, "the audiences no doubt attempted to scrutinize [Zoe's] body for signs of her buried 'black' life. As dramatic strategy, the signs of Zoe's blackness are staged in a way that—unlike a film, where the camera could zoom in for a close-up of the blue tinge of the actress's fingernails - the audience must imagine how her 'deviant' difference might be written on her body."40 In 1859, a camera cannot zoom in on the heroine's features. But, as it features cameras elsewhere in the action, the play does prompt its audience to see her in a photographic way. It prompts them to pretend to focus (as, one day, a camera could) on her complexion, to scrutinize (as, one day, a telephoto lens could) her supposed racial markers. She acts as if she is already photographed; audiences in turn act as if a camera already aids their vision. 
As a racialized Other, that is, she submits her body to surveillance (though no camera actually observes her); as an audience, her observers approve of her submission (though they train no actual camera upon her). A character in a dramatic performance and the audience witnessing that performance all act as if a subsequent visual regime, in which cameras monitor movements and individuals submit to surveillance, already governs the acts of performing, witnessing, and documenting. The play in these respects anticipates subsequent racial Others like Zoe in American history, who submit to the racist calculus of eugenics movements, to police departments with their blotters for suspects' fingerprints, to highway patrolmen using racial profiling, to the searches of airport-security personnel. The Octoroon marks one of several historic moments, at which audiences are coached to see the submitting, filming, and monitoring of Others as what "naturally" occurs in front of cameras. Many modern audiences, like Boucicault's, still respond to such coaching. They expect submission from racial Others. They feel vexation when those Others will not "naturally" submit—or, even worse, when accusatory cameras are trained on them instead.

Nineteenth-century American audiences so strongly anticipated photography's capacities to resolve the stage's issues of representation, offer an irrefutable record of authentic truths, and provide documentation of racial Others, that this play imagined these functions for photography before technology could actually provide them. Twenty-first-century audiences in turn have so deeply absorbed photography's seemingly unmediated representations, claims to present unbiased truths, and functions in documenting aliens and Others, that they read these functions back into a play that was staged prior to the technics capable of rendering them. This play looks forward to what photography and cinematography can do, that stage drama itself cannot. It "stages" an authenticity that stage performance cannot deliver, and then it acts as if a photograph can. That most twenty-first-century audiences have trouble picturing the play without imagining interracial casts, "live" and recorded performances, and zoom-lens technologies, demonstrates photography's occupation of a position that theater once held for most nineteenth-century audiences. Theater began to cede that position to photographic media as soon as The Octoroon debuted. Audiences 150 years ago predicted that photography would succeed where theater never could; audiences today are so accustomed to this success, they find it difficult to imagine the performance any other way.

Cleveland State University

\section{Notes}

I would like to thank Norman Boyer, Shawn Michelle Smith, Karl Zender, Edward Schwarzschild, Harley Erdman, Timothy Sweet, Timothy Dow Adams, Brad Barber, John 
Gerlach, and the anonymous reader-reviewers who all helped, in their own ways, with the writing of this piece.

1. Jay David Bolter and Richard Grusin, "Remediation," Configurations 4, no. 3 (September 1996): 345. Bolter and Grusin remark that "mediation" is contingent upon today's varied electronic and digital media, as they trace a "genealogy of affiliation," whereby "photography was more immediate than painting; film than photography; television than film; and now virtual reality fulfills the promise of immediacy and supposedly ends the progression" $(345,351)$. I extend their ideas to an antebellum context and propose the addition of stage performance to photography's "genealogy."

2. The following theater historians have all addressed The Octoroon: Joseph R. Roach, Cities of the Dead: Transatlantic Performance (New York: Columbia University Press, 1996); Mark Mullen, "The Work of the Public Mind," Nineteenth-Century Theater 27, no. 2 (Winter 1999); and Harley Erdman, "Caught in the Eye of the Eternal: Justice, Race, and the Camera, From The Octoroon to Rodney King," Theatre Journal 45 (1993). The following writers of cultural histories of American photography, by contrast, omit The Octoroon from their studies: Alan Trachtenberg, Reading American Photographs: Images as History, Mathew Brady to Walker Evans (New York: Farrar, Straus, and Giroux, 1989); Ed Folsom, Walt Whitman's Native Representations (New York: Cambridge University Press, 1984); Susan Williams, Confounding Images: Photography and Portraiture in Antebellum American Fiction (Philadelphia: University Press of Pennsylvania, 1997); Carol Shloss, In Visible Light: Photography and the American Writer, 1840-1940 (New York: Oxford University Press, 1987); and Shawn Michelle Smith, American Archives: Gender, Race, and Class in Victorian Visual Culture (Princeton: Princeton University Press, 1999). Only Jennifer Green-Lewis, in Framing the Victorians: Photography and the Culture of Realism (Ithaca: Cornell University Press, 1996), mentions The Octoroon in passing (192). Erdman foregrounds the play's photographic motifs, and explores its relevance for theatrical traditions, mixed-race identities, and jurisprudence. I agree with Erdman's conclusions, and explore the play's representation of photography in relation to blackface's established discourses.

3. Readers interested with the body in performance, especially Roach; Jennifer DeVere Brody, Impossible Purities: Blackness, Femininity, and Victorian Culture (Durham: Duke University Press, 1998); and Saidiya Hartman, Scenes of Subjection: Terror, Slavery, and Self-Making in Nineteenth-Century America (New York: Oxford University Press, 1997), have used The Octoroon to enhance critical understandings of the performance of "race." The following theories of visuality further critical conceptions of visual culture and photography, without making specific reference to The Octoroon: John Tagg, The Burden of Representation: Essays on Photographies and Histories (Amherst: University of Massachusetts Press, 1988); Jonathan Crary, "Modernizing Vision," Vision and Visuality, ed. Hal Foster (Seattle: Bay Press, 1988); Allan Sekula, "On the Invention of Photographic Meaning," Thinking Photography, ed. Victor Burgin (London: Macmillan, 1982); Laura Wexler, "Seeing Sentiment: Photography, Race, and the Innocent Eye," in Female Subjects in Black and White: Race, Psychoanalysis, Feminism, ed. Elizabeth Abel, Barbara Christian, and Helene Moglen (Berkeley: University of California Press, 1997); and Nancy Armstrong, Fiction in the Age of Photography: The Legacy of British Realism (Cambridge: Harvard University Press, 1999). 
4. Scott Boltwood, "The Ineffaceable Curse of Cain': Race, Miscegenation, and the Victorian Staging of Irishness," Victorian Literature and Culture 29, no. 2 (September 2001); Brody and others have contributed studies of Boucicault from outside of the field of theater history, notably in terms of Irish-American culture (Boltwood), and Louisiana Creole culture (Brody).

5. George Aiken's dramatic version of Uncle Tom's Cabin had already been drawing audiences for years when Boucicault's play opened. Uncle Tom's Cabin, or Life Among the Lowly: A Drama in Six Acts, 1852 (New York: Garland, 1994). Jeffrey D. Mason explains of Aiken's play that "anyone planning to stage Uncle Tom's Cabin had to confront the question of whether the audience would take the black characters and their problems at all seriously." Jeffrey D. Mason, Melodrama and the Myth of America (Bloomington: Indiana University Press, 1993), 118. Aiken and Boucicault alike, then, told solemn and melodramatic blackface stories, to audiences more accustomed to blackface slapstick and burlesque. For information on blackface subversiveness and minstrel traditions, I draw upon the following: Alexander Saxton, "Blackface Minstrelsy and Jacksonian Ideology," in Locating American Studies: The Evolution of a Discipline, ed. Lucy Maddox (Baltimore: The Johns Hopkins University Press, 1999); Robert Toll, Blacking Up: The Minstrel Show in Nineteenth-Century America (New York: Oxford University Press, 1974); John G. Blair, "The Emergence of an American Mentality: The Cultural Work of Antebellum Stage Entertainments," in Ceremonies and Spectacles: Performing American Culture, ed. Teresa Alves, Teresa Cid, and Heniz Ickstadt (Amsterdam: Vu University Press, 2000); W. T. Lhamon, Jr., Raising Cain: Blackface Performance from Jim Crow to Hip Hop (Cambridge: Harvard University Press, 1998); William J. Mahar, Behind the Burnt Cork Mask: Early Blackface Minstrelsy and Antebellum American Culture (Chicago: University of Illinois Press, 1999); Eric Lott, Love and Theft: Blackface Minstrelsy and the American Working Class (New York: Oxford University Press, 1993) and "White Like Me: Racial Cross-Dressing and the Construction of American Whiteness," in Cultures of United States Imperialism, ed. Amy Kaplan and Donald E. Pease (Durham: Duke University Press, 1993).

6. Boucicault wrote and produced (and many of his readers cite) a later version of this play, which debuted in London in 1861. Significantly, this latter edition ended with the "miscegenated" marriage (between George and Zoe) that the American version did not depict. To stay true to photography's American stage debut, I refer to the text of the earlier, American version.

7. Oliver Wendell Holmes, "Stereographs and Stereoscopes," Atlantic Monthly 3, no. 20 (June 1859): 744.

8. R. H. E., "My Photograph," Godey's Lady's Book (April 1867): 341.

9. Marcus Aurelius Root, The Camera and the Pencil, or the Heliographic Art, 1864, (Pawlet, VT: Helios Press, 1971), 140; Root's emphasis.

10. Walt Whitman, "Visit to Plumbe's Gallery," Brooklyn Daily Eagle, July 2, 1846. The Gathering Forces of Walt Whitman, ed. Cleveland Rogers and John Black (New York: Putnam's Sons, 1920), 2:116.

11. Nathaniel Hawthorne, Centenary Edition of the Works of Nathaniel Hawthorne, ed. William Charvat, et al. (Columbus: Ohio State University Press, 1962), 8:178. 
12. Oliver Wendell Holmes, "Doings of the Sunbeam," Atlantic Monthly 12, no. 69 (July 1863): 9.

13. Root, 43-44.

14. Dion Boucicault, The Octoroon, in The Longman Anthology of American Drama, ed. Lee A Jacobs (New York: Longman, 1982), 105. Hereafter cited parenthetically in the text.

15. The term "octoroon," denoting someone one-eighth black, as the offspring of a quadroon and a Caucasian, apparently was a new coinage in 1859. Mark Mullen remarks "that no one seemed quite sure what an 'octoroon' was" when the play debuted (89), and the Oxford English Dictionary records Boucicault's title as the first known use of the word in the language.

16. Mullen, 111.

17. Boltwood, 147.

18. Brody, $50,52$.

19. Robyn Wiegman determines that "for the African (American) in the late eighteenth and nineteenth centuries ... the ability to be gendered marked the entrance to the human, public community, providing both civic roles (such as the reproduction of mothering) while simultaneously fragmenting citizenship according to a deeply exclusive masculine universalism" (68). Zoe's ungendered self-presentation, as "an unclean thing," furthers this "fragmenting" tendency.

20. The pro-slavery New York Herald objected to the "Nigger minstrelsy or nigger five-act melodramas" such as The Octoroon (quoted in Mullen, p. 95), while the New York Times Review observed of the production that "a negro in the North is never comic unless he has a banjo in his hands—and all the comedy [in The Octoroon] comes from the negroes" "Winter Garden 'The Octoroon," New York Times Review [December 8, 1859]: 6). The play, then, operated within minstrel traditions, characterized by blackface, plantation melodies, and stereotyped behaviors.

21. Lott, "White Like Me," 475.

22. Previous melodramas on the American stage had featured racial intermediaries of Zoe's ilk. In Aiken's version of Uncle Tom's Cabin, Jeffrey Mason explains, "the actors in the 1850s, who were white, probably did not play them in classic black face with nappy wigs. If so, the scene may have resembled any other encounter between a troubled white couple who faced the classic melodramatic situation of having to deal with misfortune visited upon them by some unseen, external agency" (119). In Boucicault's play, Agnes Robertson, the playwright's wife, probably played Zoe in a similar fashion, making the octoroon look like any conventional stage heroine. Audiences for both of these plays coped with the undesired knowledge that misfortune could come about through external circumstances, and not only through some internal flaw or biological quality in the victim.

23. Blair, 75 .

24. Hartman, 28.

25. Wexler, 175.

26. Root, 43-44.

27. Most instructive here is Roach, for whom Zoe's sale represents an instance of "surrogation," the "symbolic substitution . . . of a white-appearing body for a black one, of 
gender difference for racial difference, and of one community for another." "In the defining event of commercial exchange, from flesh to property," Roach remarks of her sale, "the object of desire mutates and transforms itself, from African to Woman: its nearly invisible but fatal blackness makes it available; its whiteness somehow makes it clean" $(58,61)$.

28. For these observations, I am indebted to Hartman, who writes, "The fungibility of the commodity makes the captive body an abstract and empty vessel vulnerable to the projection of others' feelings, ideas, desires, and values" (21). Furthermore, "The assimilative character of empathy can be blamed in part for this [ability to imagine oneself in a slave's place], for approximation overtakes the proximity essential to the ethical conduct, and the violence of this obliteration and assimilation is no less great, albeit of a different character, than the racist antipathy that can only envision the enslaved as object and dehumanized other" (35).

29. Tagg, 4.

30. Armstrong, 21.

31. Holmes, 11.

32. Green-Lewis, 53.

33. Erdman 337.

34. Crary, 42.

35. Bolter and Grusin, 343.

36. For information on Boucicault's "stage pictorialism" as a precursor to early photoplays, I am indebted to Ben Brewster and Lea Jacobs's Theater to Cinema: Stage Pictorialism and the Early Feature Film (New York: Oxford University Press, 1997).

37. Lott, Love and Theft, 73.

38. Henry B. Wonham, Playing the Races: Ethnic Caricature and American Literary Realism (New York: Oxford University Press, 2004), 88.

39. Philip Auslander, Liveness (New York: Routledge, 1999), 51.

40. Brody, 49. 